Article

\title{
Oligonucleotide Detection and Optical Measurement with Graphene Oxide in the Presence of Bovine Serum Albumin Enabled by Use of Surfactants and Salts
}

\author{
Florentin R. Nitu, Jorge S. Burns *(1) and Mariana Ionită * \\ Faculty of Medical Engineering, University Politehnica of Bucharest, Gh Polizu 1-7, 011061 Bucharest, Romania; \\ florentinnitu@hotmail.com \\ * Correspondence: jpjsburns@gmail.com (J.S.B.); mariana.ionita@polimi.it (M.I.); Tel.: +40-722-241234 (J.S.B.); \\ +40-21-4022709 (M.I.)
}

Received: 30 March 2020; Accepted: 20 April 2020; Published: 23 April 2020

\begin{abstract}
As graphene oxide-based oligonucleotide biosensors improve, there is a growing need to explore their ability to retain high sensitivity for low target concentrations in the context of biological fluids. Therefore, we innovatively combined assay milieu factors that could influence the key performance parameters of DNA hybridization and graphene oxide (GO) colloid dispersion, verifying their suitability to enhance oligonucleotide-GO interactions and biosensor performance. As a model system, we tested single-strand (ss) DNA detection in a complex solution containing bovine serum albumin (BSA) and salts with surfactants. A fluorescein conjugated 30-mer oligonucleotide ssDNA probe was combined with its complementary cDNA target, together with solute dispersed GO and either non-ionic (Triton X-100 and Tween-20) or anionic sodium dodecyl sulfate (SDS) surfactants. In this context, we compared the effect of divalent $\mathrm{Mg}^{2+}$ or monovalent $\mathrm{Na}^{+}$salts on $\mathrm{GO}$ binding for the quench-based detection of specific target-probe DNA hybridization. GO biosensor strategies for quench-based DNA detection include a "turn on" enhancement of fluorescence upon target-probe interaction versus a "turn off" decreased fluorescence for the GO-bound probe. We found that the sensitive and specific detection of low concentrations of oligonucleotide target was best achieved using a strategy that involved target-probe DNA hybridization in the solution with a subsequent modified "turn-off" GO capture and the quenching of the unhybridized probe. Using carefully formulated assay procedures that prevented GO aggregation, the preferential binding and quenching of the unhybridized probe were both achieved using 0.1\% BSA, $0.065 \%$ SDS and $6 \mathrm{mM} \mathrm{NaCl}$. This resulted in the sensitive measurement of the specific target-probe complexes remaining in the solution. The fluorescein-conjugated single stranded probe (FAM-ssDNA) exhibited linearity to cDNA hybridization with concentrations in the range of $1-8 \mathrm{nM}$, with a limit of detection equivalent to 0.1 pmoles of target in $100 \mu \mathrm{L}$ of assay mix. We highlight a general approach that may be adopted for oligonucleotide target detection within complex solutions.
\end{abstract}

Keywords: graphene oxide; surfactants; fluorescence quenching; optical DNA sensor

\section{Introduction}

Graphene is a two-dimensional (2D) material with a single layer of carbon atoms arranged in a hexagonal lattice [1], with important electrical, optical, mechanical, chemical properties. Most of the applications of graphene and its derivatives focus on device fabrication, energy storage, flexible electronics, solar cells, metamaterials, optoelectronic devices [2-5] and biosensors [6-9]. Graphene and functionalized graphene oxide or reduced graphene oxide $(\mathrm{GO}, \mathrm{rGO})$ are used in electrochemical, 
electronic and optical biosensors for DNA detection [7,8,10]. 2D graphene-based materials of high surface area exhibit broad-spectrum fluorescent quenching capacity [11]. Recent optical detection platforms include the use of fluorescently labeled oligonucleotide probes that can serve as Förster resonance energy transfer (FRET) donors and graphene nanomaterials as quenchers [12,13]. For DNA biosensors, it is generally considered that ssDNA can stably adsorb onto GO due to pi-pi $(\pi-\pi)$ stacking interactions [14-16] and possibly due to hydrogen bonding [17] between the nitrogenous bases and the oxidized sheets of GO. In contrast, double-stranded DNA (dsDNA) [18] has a lower affinity and is less capable of forming GO-stacking interactions, since dsDNA internalized aromatic base ring structures are involved in base-stacking interactions, and they remain hidden by negatively charged DNA backbone phosphate groups. Substrate binding selectivity is critical to many aptamer-binding applications. The use of surfactants offers a complementary approach to modulate the aptamer binding selectivity to GO, while at the same time providing a non-covalent modifier that can improve graphene oxide solute dispersion. It was reported that a nonionic surfactant, such as Triton X-100, can block the formation of dsDNA/GO complexes [19]. Regarding an oligonucleotide aptamer-based sensor for a drug, Tween-20, another non-ionic surfactant was used to prevent the nonspecific binding of cocaine to GO decorated with (poly-C) DNA [20]. Another application that was advantageous for biosensor development was the observation that colloidal graphene sheets were stable for over a year in aqueous sodium dodecyl sulfate (SDS) $>40 \mu \mathrm{M}$ [21]. An additional material advantage over other methods relates to the tunable physiochemical properties of graphene derivatives, introducing scope for implementation in plasmonic devices [22] that are well suited for integrated optics technologies and future single-chip robust sensors of low energy consumption for point-of-care devices [23]. In studies using atomic force microscopy (AFM) to investigate the DNA association in the dsDNA-GO complex, dsDNA could aggregate on the GO surface in the presence of salts. Moreover, GO tended to stack into a multi-layer structure in the presence of dsDNA, indicating that dsDNA could simultaneously interact with the two sides of the GO sheets [24]. These observations highlighted how subtle alterations in conditions might strongly influence biosensor performance.

As depicted in Figure 1, most authors describe target "turn on" methods (detection-1), where GO-dependent probe FRET quenching is diminished by target-induced probe desorption $[14,25,26]$. Others have proposed a modified "turn off" strategy whereby target-probe complexes remaining in the solution emit fluorescence, but excess unbound probes are quenched (detection-2) $[14,27,28]$. Additional factors affecting DNA-GO interactions and fluorescence quenching that can influence assay performance include (i) oligonucleotide probe length [29], (ii) relative target concentration and GO quality [30], (iii) non-specific interactions [31], (iv) GO colloid dispersion [21] (v) GO surface heterogeneity [32], (vi) available surface area [33], (vii) dynamic fluorescent quenching effects [34] and (viii) the ionic strength of the sensing milieu [35].

These concerns become critical when detecting low levels of the target in physiological media where salts, ions and biomolecules may adversely affect the GO-suspended flakes. While GO is known to be highly stable in water, when transferred to cell culture media or buffer it ordinarily undergoes aggregation [36-40]. All forms of graphene may be altered by interacting with the physiological media components found in cell culture media or biological fluids that change the size, shape or surface chemistry of the 2D sheet [32,41]. For example, aromatic amino acids such as tyrosine, phenylalanine and tryptophan, capable of $\pi-\pi$ interactions [42], can promote the formation of a protein corona on the GO surface [43], causing the irreversible aggregation of suspended GO flakes.

The phenomenon of fluorescence quenching by a photoinduced electron transfer (PET) between a fluorescent dye and a nucleotide base, upon the homogeneous hybridization of the oligonucleotide probe with its complementary target sequence, must not be overlooked [44,45] (Figure 2). This sequence-specific reversible quenching depends upon the proximity of the fluorescent (FAM) moiety and guanine, with the quenchable dye acting as an electron acceptor in the excited state and the guanine base acting as an electron donor [46]. This PET can serve as a useful means of monitoring the formation of the hybridized target-probe duplex DNA. 
Detection-1

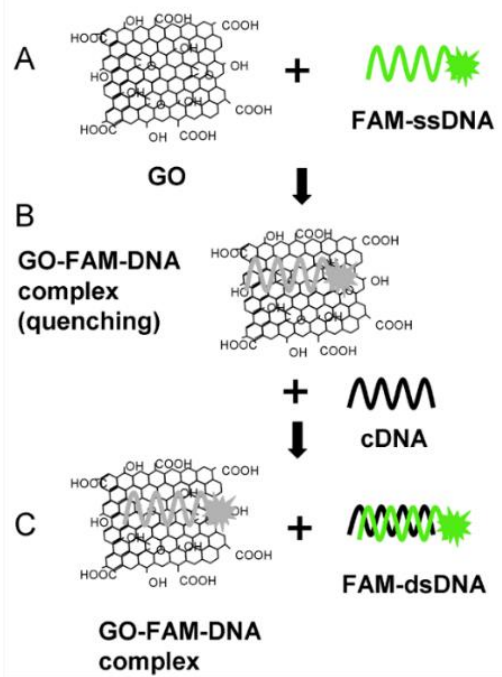

Detection-2

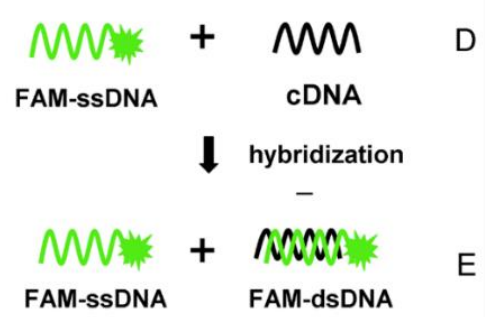

I + GO

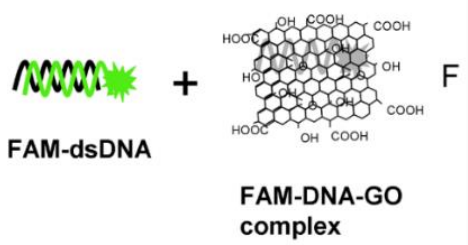

Figure 1. Schematic representation of oligonucleotide detection via hybridization to ssDNA probe adsorbed to a graphene oxide (GO) surface (detection-1) or in solution (detection-2). (A) The fluorescein-conjugated single stranded probe (FAM-ssDNA) mixed with graphene oxide (GO), results in (B) probe surface adsorption and fluorescence quenching. The addition of a complementary cDNA target (cDNA) results in (C) the preferential desorption of hybridized double-stranded DNA (FAM-dsDNA) with the restoration of fluorescence. For detection-2 (D), the first target and probe hybridization in the solution resulted in (E) an excess of free probes, (FAM-ssDNA) hybridized probes and targets. The addition of GO results in $(\mathbf{F})$ the adsorption and quenching of excess unhybridized probes (FAM-ssDNA-GO complex) and quantifiable fluorescent FAM-dsDNA proportional to the target concentration.

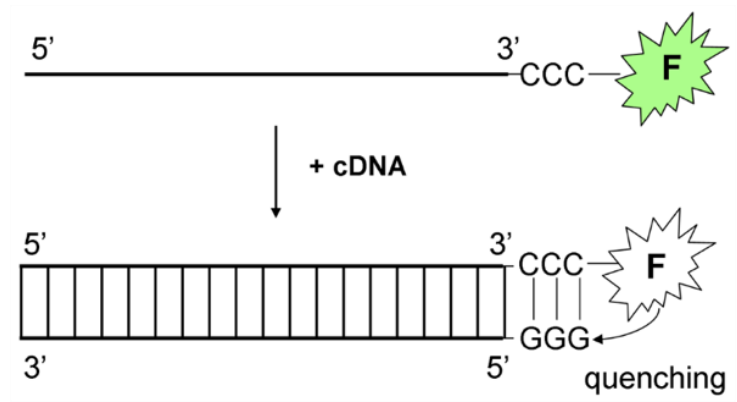

Figure 2. Schematic representation of FAM-DNA quenching due to photoinduced electron transfer (PET) upon hybridization with a guanine-containing complementary oligo cDNA target.

We compared the non-ionic surfactants Triton-X-100 and Tween-20 and their ability to modulate FAM-labeled oligonucleotide binding to GO in the presence of divalent $\left(\mathrm{Mg}^{2+}\right)$ or monovalent $\left(\mathrm{Na}^{+}\right)$ ions, measured by changes in fluorescent signals. Our objective was to see whether we could quantitatively detect low levels of unlabeled target molecules in a mixture of protein, surfactants and salts, resembling complex physiological solutions. We describe the establishment of a label-free homogeneous GO-based assay in a complex physiological-like solute. This allowed us to detect and quantify target cDNA in the concentration range of $1-8 \mathrm{nM}$, equivalent to $0.1-0.8$ picomoles of 30-mer ssDNA targets in our $100 \mu \mathrm{L}$ assay volume. 


\section{Materials and Methods}

\subsection{Reagents}

Graphene oxide (GO) $2 \mathrm{mg} / \mathrm{mL}$, dispersion in $\mathrm{H}_{2} \mathrm{O}$, cat. No. 763,705 Sigma, magnesium chloride $98.0 \%\left(\mathrm{MgCl}_{2}\right)$, sodium chloride ( $\left.\mathrm{NaCl}\right)$, sodium dodecyl sulfate (SDS), Triton X-100, Tween-20, bovine serum albumin (BSA), were purchased from Sigma-Aldrich (St. Louis, MO, USA). Regarding a study of nucleic acid-GO interactions [47], the T7 RNA polymerase promoter sequence DNA aptamer probe sequence was supplied, $3^{\prime}$ labeled with 6-fluorescein amidite (6-FAM), according to the sequence 5'-TTT CAA CAT CAG TCT GAT AAG CTA TCT CCC-3'/6-FAM (referred to as FAM-DNA). The corresponding single-stranded DNA target molecule with the complementary sequence $5^{\prime}$-GGG AGA TAG CTT ATC AGA CTG ATG TTG AAA-3' (cDNA) was purchased from Integrated DNA Technologies, Inc. (Coralville, IA, USA).

\subsection{Graphene Oxide Nanomaterial Sample}

The graphene oxide had a $42-52 \%$ carbon content (dry basis) and $44-45 \%$ oxygen content for the monolayer sheets with a mean diameter of $<22 \mu \mathrm{m}, 90 \%<50 \mu \mathrm{m}$ by laser diffraction (manufacturer's specifications, Sigma-Aldrich). The commercial GO, provided as a $2 \mathrm{mg} / \mathrm{mL}$ dispersion in water, was homogeneously gently re-dispersed by water bath sonication $(300 \mathrm{~W}, 40 \mathrm{kHz})$ under ambient conditions for $10 \mathrm{~min}$ before use and then adjusted to $10 \mathrm{mM}$ with Tris- $\mathrm{HCl} \mathrm{pH} 8.0$ buffer during the assay [48]. The critical micelle concentration (CMC) at $20-25^{\circ} \mathrm{C}$ in water for the surfactants used were as follows: Triton X-100 $(\mathrm{CMC})=0.2-0.9 \mathrm{mM}$ or $0.0125-0.0562 \%$, Tween-20 $(\mathrm{CMC})=0.06 \mathrm{mM}$ or $0.0074 \%$, SDS $(\mathrm{CMC})=7-10 \mathrm{mM}$ or $0.202-0.289 \%$ (according to manufacturer's specifications, Sigma-Aldrich). For each surfactant, the concentrations were chosen to be above CMC; this optimized GO dispersion and established the effective blocking of non-specific binding sites.

\subsection{Spectrofluorimeter Measurements}

The carboxyfluorescein (FAM)-labeled single-stranded probe (5'-TTT CAA CAT CAG TCT GAT AAG CTA TCT CCC-3'/6-FAM) was hybridized with the complementary target oligo DNA (c-DNA): $5^{\prime}$-GGG AGA TAG CTT ATC AGA CTG ATG TTG AAA-3') in $10 \mathrm{mM}$ Tris-HCl pH 8.0 buffer at $23^{\circ} \mathrm{C}$, before or after the addition of $10 \mu \mathrm{g} / \mathrm{mL}$ or $5 \mu \mathrm{g} / \mathrm{mL}$ of GO. After incubation at room temperature for $1 \mathrm{~h}$, the fluorescence emission intensity was recorded at $535 \mathrm{~nm}$, with five reads per well, using a TECAN Spark Fluorescence microplate reader (Tecan Trading AG., Männedorf, Switzerland). The adsorption kinetics was monitored by the same microplate reader at $23^{\circ} \mathrm{C}$. Stock solutions were freshly prepared before the experiment. It was crucial to first add SDS surfactant to GO before BSA, in order to avoid aggregation and maintain GO dispersion. Oligo DNA stock solutions were made containing $0.1 \mathrm{mg} / \mathrm{mL}$ BSA. GO stock solution contained $0.1 \%$ SDS and $0.1 \mathrm{mg} / \mathrm{mL}$ BSA. A total of $100 \mu \mathrm{L}$ of final volume was used for all the samples distributed into black Costar 96-well flat-bottomed plates, cat. \# 3915. For cDNA detection, several concentrations of FAM-ssDNA were used: 1, 2, 4 and $8 \mathrm{nM}$ with the same concentrations of c-DNA, in 6 and $60 \mathrm{mM} \mathrm{NaCl}, 1 \mathrm{mM}$ ethylenediaminetetraacetic acid (EDTA), $10 \mathrm{mM}$ Tris-HCl buffer, $\mathrm{pH}$ 8.0, FAM-DNA: cDNA = 1:1. A total of $10 \mu \mathrm{g} / \mathrm{mL}$ of GO was added to the ssDNA or ssDNA + cDNA samples and the fluorescence signal was monitored.

\subsection{Statistical Analysis}

Raw data were presented using the mean and standard deviation. To determine the statistical significance, an independent t-test analysis (two populations) was performed in Origin v. 6.0.3.1.

\section{Results}

In order to detect the target cDNA in complex media, GO had to be maintained as a dispersed colloid and non-specific binding to GO had to be minimized. We compared two non-ionic detergents, 
Triton X-100, Tween-20 in the presence of $\mathrm{MgCl}_{2}$ and one ionic detergent, sodium dodecyl sulfate (SDS), in the presence of bovine serum albumin and $\mathrm{NaCl}$.

\subsection{PET Quenching of FAM-DNA Due to Hybridisation with cDNA}

In Figure 3A, a control of FAM-DNA + cDNA was used to establish quenching due to photoinduced electron transfer (PET) after hybridization. The amount of PET quenching increased with $\mathrm{MgCl}_{2}$ concentrations from $\approx 16 \%$ quenching without $\mathrm{MgCl}_{2}, \approx 60 \%$ quenching at $1 \mathrm{mM} \mathrm{MgCl} 2$ and $\approx 70 \%$ quenching at $10 \mathrm{mM} \mathrm{MgCl} 2$.

A
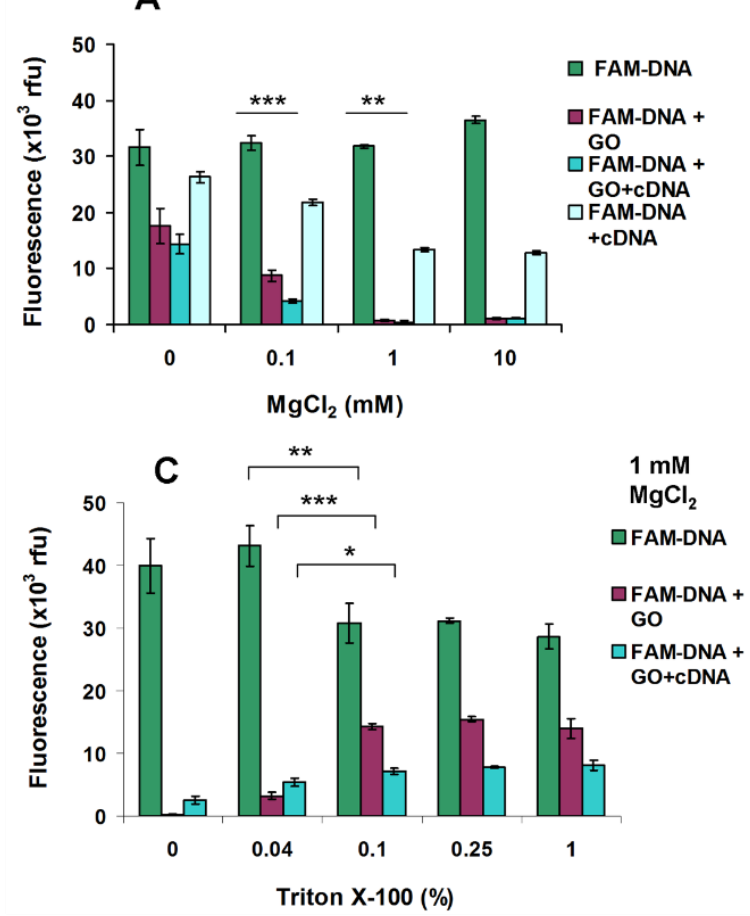

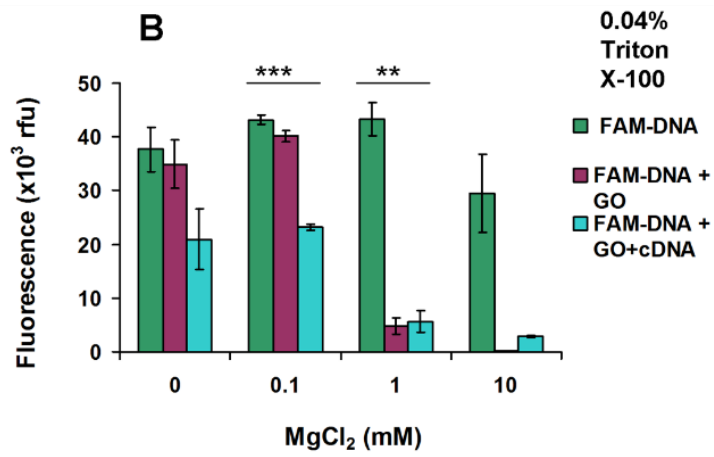

Figure 3. Triton $\mathrm{X}-100$ reduced the FAM-DNA binding to GO in the presence of $\mathrm{MgCl}_{2}$. (A) The effect of $\mathrm{MgCl}_{2}$ concentration on fluorescence signal from single stranded FAM-DNA alone and with the addition of GO, with or without the CDNA target. FAM-DNA combined with cDNA alone was compared as a control. (B) The effect of $0.04 \%(0.64 \mathrm{mM})$ Triton X-100, on FAM-DNA/GO interaction with increased $\mathrm{MgCl}_{2}$ concentration. (C) The effect of Triton X-100 concentration on FAM-DNA/GO interaction at a constant of $1 \mathrm{mM} \mathrm{MgCl}_{2}$ in $10 \mathrm{mM}$ Tris- $\mathrm{HCl}$, $\mathrm{pH}$ 8.0. For (A-C), $100 \mathrm{nM} \mathrm{L}^{-1}$ FAM-ssDNA, $100 \mathrm{nM} \mathrm{L}^{-1} \mathrm{cDNA}$ and $10 \mu \mathrm{g} / \mathrm{mL}$ GO. All the data were acquired at $23{ }^{\circ} \mathrm{C}$ and $1 \mathrm{~h}$ incubation time. Error bars represent standard deviation (SD) of $n=3$. $p$-values; ${ }^{*} p \leq 0.1,{ }^{* *} p \leq 0.01, * * * p \leq 0.001$.

\subsection{FRET Quenching of FAM-DNA Due to Adsorption to GO}

FAM-ssDNA and complementary ssDNA target (cDNA) would be expected to be negatively charged at the working $\mathrm{pH}(8.0)$, reflecting the influence of the salt concentration on GO binding. In the absence of $\mathrm{MgCl}_{2}$, the addition of GO to $100 \mathrm{nM}$ FAM-DNA led to modest FRET quenching $\left(\approx 30 \%\right.$ ) (Figure $3 \mathrm{~A}$ ), which reached over $95 \%$ for $1 \mathrm{mM}$ and $10 \mathrm{mM} \mathrm{MgCl}_{2}$. In contrast, use of the surfactants Triton X-100 (Figure 3B) or Tween-20 (Figure 4B) helped reduce FRET quenching at these higher $\mathrm{MgCl}_{2}$ concentrations to a comparable extent $(\approx 85 \%)$ for $1 \mathrm{mM}$ and $(\approx 90 \%) 10 \mathrm{mM} \mathrm{MgCl}$. Triton X-100 was most effective at reducing FAM-DNA binding to GO at $0.1 \mathrm{mM}$, resulting in no significant quenching. Notably, the fluorescence value for GO + FAM-DNA + cDNA at $0.1 \mathrm{mM} \mathrm{MgCl} 2$ in the presence of Triton X-100 (Figure 3B) was similar to the fluorescence value found at $0.1 \mathrm{mM} \mathrm{Cl}_{2}$, which is attributable to the PET quenching of FAM-DNA + cDNA. Nonetheless, at the higher $1 \mathrm{mM}$ $\mathrm{MgCl}_{2}$ concentration, the low fluorescence $\approx 5 \times 10^{3}$ relative fluorescence units (r.f.u.) of FAM-DNA 
$+\mathrm{GO}+\mathrm{cDNA}$ (Figure 3B) was below the corresponding control value $\left(15 \times 10^{3}\right.$ r.f.u.) (Figure 3A). Even when increasing Triton X-100 concentrations in the presence of $1 \mathrm{mM} \mathrm{MgCl}{ }_{2}$ (Figure 3C), the recovery of FRET quenching reached a maximum of $(\approx 50 \%)$; thus, in comparison to $0.1 \mathrm{mM} \mathrm{MgCl} 2$, some FAM-DNA bound to GO could not be desorbed by Triton X-100, suggesting that there were high as well as low affinity sites for FAM-DNA binding. Notably, there was a significant quenching difference between $0.04 \%$ and $0.1 \%$ Triton X-100, with no further effect observed for higher Triton X-100 concentrations. Triton X-100 concentrations of $0.1 \%, 0.25 \%$ and $1 \%$ introduced very stable and consistent outcomes with respect to the fluorescent intensity for FAM-DNA, the fluorescent intensity for FAM-DNA + GO and the halving of the fluorescence signal upon the further addition of cDNA. Triton X-100 could reduce the interaction between GO and FAM-DNA, making this more critically dependent on the presence of $\mathrm{MgCl}_{2}$.

\subsection{Modulation of DNA Binding to GO by Tween-20, in the Presence of $\mathrm{MgCl}_{2}$}

Figure 4 highlights the modulation of DNA binding to GO by Tween-20, a polyoxyethylene sorbitol ester, which is another biocompatible nonionic surfactant widely used in biochemistry. In the presence of $\mathrm{Mg}^{2+}$ ions, three main effects of Tween-20 could be observed. Firstly, compared to the initial 30-40 $\times 10^{3}$ r.f.u range of values for FAM-DNA fluorescence without Tween-20 (Figure 4A), the presence of Tween-20 made the baseline levels of fluorescence for FAM-DNA much more consistent $\left(\approx 30 \times 10^{3}\right.$ r.f.u) (Figure $\left.4 \mathrm{~B}\right)$. This indicated the surfactant's effectiveness in reducing non-specific binding variability and establishing stable assay conditions. Secondly, Tween-20 could significantly increase the fluorescence signal after the addition of GO (Figure 4B), which is especially noticeable when overcoming the virtually complete quenching seen at the higher 1 and $10 \mathrm{mM} \mathrm{MgCl}_{2}$ concentrations in the absence of Tween-20 (Figure 4A). Tween-20 could increase FAM-DNA + cDNA + GO fluorescence, even at higher $\mathrm{MgCl}_{2}$ concentrations (Figure $4 \mathrm{~B}$ ). The selective binding of ssDNA as opposed to dsDNA was not fully achieved, since both were present in gel electrophoresis of the sample supernatant (Supplementary Figure S1); nonetheless, relatively more ssDNA than dsDNA was bound to GO (Supplementary Table S1). Presumably, Tween-20 mainly blocked low affinity rather than high affinity oligonucleotide binding sites on the GO surface. Thirdly, changes in PET quenching were relatively low, indicating that Tween-20 did not significantly influence the interactions involved in DNA hybridization.

A

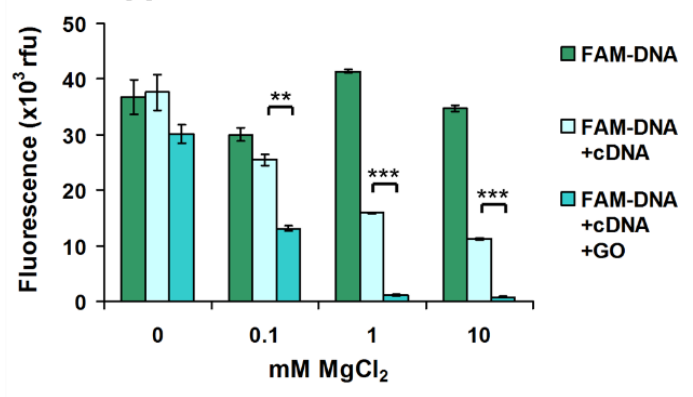

B

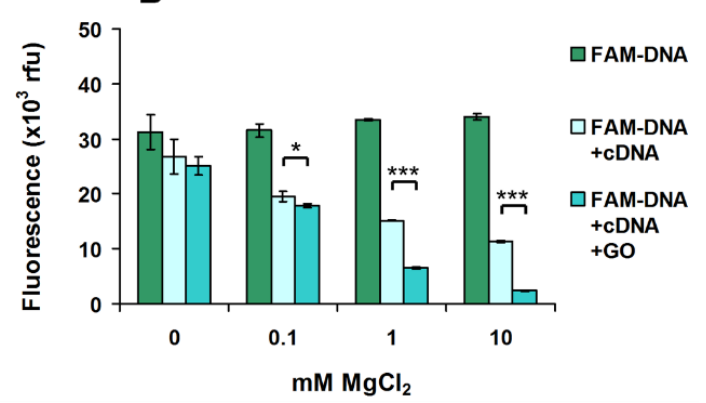

Figure 4. In the presence of $\mathrm{MgCl}_{2}$, Tween-20 did not alter FAM-DNA/cDNA hybridization, but reduced subsequent GO interaction. (A) The effect of increasing $\mathrm{MgCl}_{2}$ concentration on FAM-DNA/cDNA hybridization and subsequent interaction with GO. (B) The effect of $0.01 \%$ Tween-20 on the experimental conditions of (A). For (A,B), $25 \mathrm{nM} \mathrm{L}^{-1}$ FAM-DNA/cDNA hybridization for $60 \mathrm{~min}$ at room temperature was followed by the addition of $10 \mathrm{ug} / \mathrm{mL}$ GO and fluorescence was measured after $1 \mathrm{~h}$. A total of 25 nM L ${ }^{-1}$ FAM-ssDNA, $25 \mathrm{nM} \mathrm{L}^{-1}$ cDNA, (FAM-ssDNA:cDNA molar ratio $=1: 1$ ). Error bars represent $\mathrm{SD}$ of $n=3$. $p$-values; ${ }^{*} p \leq 0.1,{ }^{* *} p \leq 0.01,{ }^{* * *} p \leq 0.001$.

\subsection{Modulation of DNA Binding to GO by SDS, BSA and $\mathrm{NaCl}$}

With the consideration of the previous data, indicating divalent ions may promote excessive GO-oligonucleotide interaction (possibly through the formation of salt bridges in addition to charge 
screening [49], with only modest amelioration from surfactants), we chose instead to test the influence of monovalent $\mathrm{Na}^{+}$ions that, unlike $\mathrm{Mg}^{2+}$, would not precipitate SDS. This surfactant introduced the potential advantage of being able to denature BSA [50] to subsequently prevent BSA-induced GO aggregation. Adopting the two-step strategy (detection 2) of first performing solute target-probe hybridization (with quenching due to PET) before GO adsorption (with quenching due to FRET), we used $0.065 \%$ SDS and $0.1 \%$ BSA in the presence of $6 \mathrm{mM} \mathrm{NaCl}$. Keeping a 1:1 ratio of probe-to-target for a FAM-DNA concentration range of 1-8 $\mathrm{nM}$, the combination of BSA and SDS was very effective at blocking the non-specific binding of FAM-DNA, resulting in a very linear $\left(R^{2}=0.9994\right)$ concentration-dependent measurement (Figure 5A,C). There was a consistent quenching of FAM-DNA by $\mathrm{GO}$, close to $50 \%$, independent of the probe concentration (Figure $5 \mathrm{~B}$ ), indicating a stable equilibrated degree of interaction and FRET quenching between the FAM-DNA probe and GO at the particular salt concentration of $6 \mathrm{mM} \mathrm{NaCl}$. There was an anticipated FAM-DNA concentration-dependent increase in PET quenching (Figure 5B), with a linear relationship (Figure 5C) indicative of more hybridization at higher target-probe concentrations. Whereas at $1 \mathrm{nM}$ FAM-DNA, quenching due to PET was just over half that due to FRET, at $8 \mathrm{nM}$ FAM-DNA, the amount of quenching due to PET slightly exceeded that due to FRET (Figure 5B). Upon the second-step addition of GO to the 1 nM FAM-DNA + cDNA mixture, the original amount of FAM + GO FRET quenching alone was modestly but significantly increased by $10 \%(p<0.05)$. For $8 \mathrm{nM}$ FAM-DNA, the fluorescence of GO quenching upon binding the hybridized target-probe dsDNA was only $20 \%(p<0.05)$ more than the GO quenching of the FAM-DNA probe alone. These modest values would be consistent with the GO treatment of pre-hybridized FAM-DNA + cDNA, resulting in the GO quenching of excess ssDNA unbound probes.

A

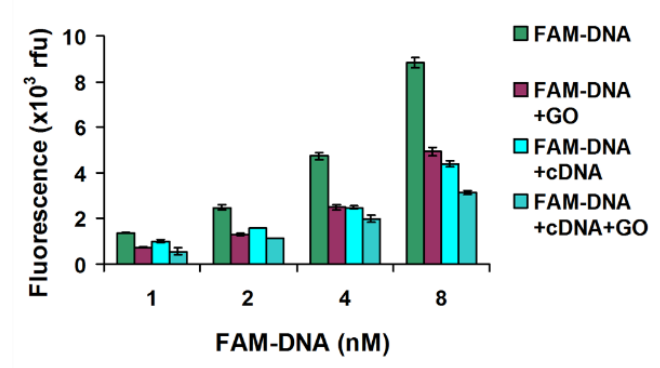

C

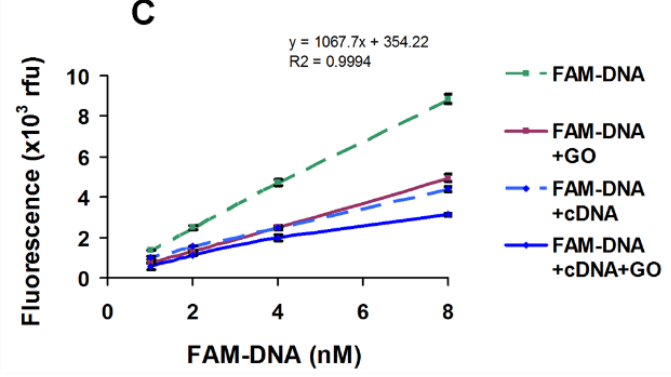

B

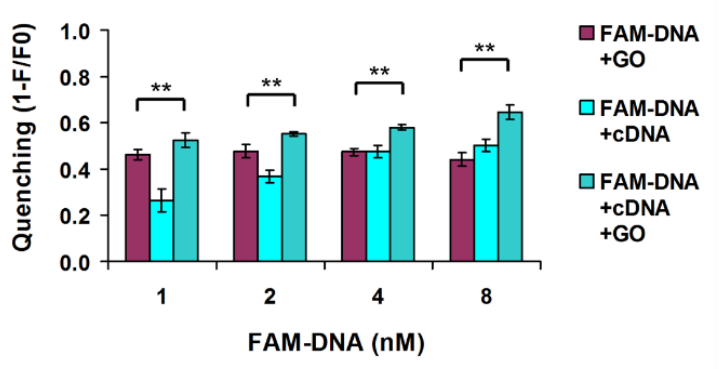

Figure 5. FAM-DNA bound to GO in the presence of bovine serum albumin (BSA), sodium dodecyl sulfate (SDS) and sodium chloride ( $\mathrm{NaCl}$ ). (A) Experiments using detection method 2; FAM-DNA fluorescence values were plotted as relative fluorescence units for each of the following samples: FAM-DNA alone, FAM-DNA with the addition of GO, FAM-DNA probe combined with cDNA target and pre-hybridized FAM-DNA + cDNA treated with GO, in the presence of $0.1 \% \mathrm{SDS}, 0.1 \mathrm{mg} / \mathrm{mL}$ BSA and $6 \mathrm{mM} \mathrm{NaCl}$. (B) Histogram of the extent of quenching due to FAM-DNA probe binding GO alone, reflecting FRET, upon FAM-DNA + cDNA hybridization, reflecting photoinduced electron transfer (PET), and after the addition of GO to pre-hybridized FAM-DNA + cDNA for one hour. (C) Linear plot of fluorescence values for FAM-DNA probe alone, FAM-DNA treated with GO, FAM-DNA + cDNA, and pre-hybridized FAM-DNA + cDNA treated with GO for increasing concentrations of FAM-DNA probes (from 1 to $8 \mathrm{nM}$ ) and cDNA targets in a 1:1 molar ratio. Error bars represent SD of $n=3$. $p$-value; ${ }^{* *} p \leq 0.01$. 
The quenching interactions were critically dependent on the presence of an ionic salt. When FAM-DNA + cDNA + GO were incubated without $\mathrm{NaCl}$ for $30 \mathrm{~min}$, there was no significant quenching, yet upon the addition of $60 \mathrm{mM} \mathrm{NaCl}$, there was a steep drop in fluorescence, which was virtually absent within $10 \mathrm{~min}$ (Supplementary Figure S2A). Notably, at the higher $60 \mathrm{mM} \mathrm{NaCl}$ concentration, the extent of quenching was more complete ( $>95 \%)$ than that observed for $6 \mathrm{mM} \mathrm{NaCl}$ $(\approx 50 \%)$, indicating that the strength of interactions and the extent of quenching could be modulated by the salt concentration. For $8 \mathrm{nM}$ FAM-DNA and $60 \mathrm{mM} \mathrm{NaCl}$, the kinetics of quenching due to PET and FRET was faster than the kinetics of quenching due to FRET alone, as seen by the steepness of the quenching curve (Supplementary Figure S2B). The extent of quenching due to PET for FAM-DNA + GO was slightly higher than the amount of quenching seen for FAM-DNA + cDNA + GO, indicating that the SDS, BSA and $\mathrm{NaCl}$ conditions were appropriate for the desorption of FAM-DNA by the cDNA target, thus reducing the amount of GO quenching.

\section{Discussion}

A broad principle underlying the peak performance of optical oligonucleotide biosensors concerns the careful control of key interactions that establish the specific detection of the target molecules under study and the subsequent tightly correlated transduction of a clear detection signal. Surfactants and blocking agents, such as Triton-X 100, SDS or BSA serve to control nonspecific adsorption and variations in ionic strength, via divalent $\mathrm{Mg}^{2+}$ or monovalent $\mathrm{Na}^{+}$ions, which can enhance DNA hybridization kinetics.

Graphene oxide is increasingly favored for optical oligonucleotide sensing because it can enable the discriminatory preferential binding of ssDNA versus dsDNA and also has the capacity to strongly quench a broad range of interacting fluorophores. Target oligonucleotide detection can be achieved via surface hybridization, through an interaction with a GO-bound probe (Figure 1, Detection 1) or via hybridization in the solution before reducing the non-specific background by allowing the unhybridized ssDNA probe to preferentially interact with the colloidal nanomaterial (Figure 1, Detection 2). Surface hybridization regimes have the purported advantage of presenting an immobilized layer that can focus the nucleic acid charge to concentrations not ordinarily found in solutions, consequently amplifying the signal. However, as increased ionic strength diminishes the relative importance of electrostatic interactions, the surface hybridization behavior can become more complex [51] and $\pi-\pi$ stacking and hydrogen bond interactions between the oligonucleotide and GO surface may play a greater role [52].

As noted in our earlier study using this model probe [35], upon the addition of target cDNA to the FAM-DNA probe in the presence of GO, the fluorescent intensity did not necessarily increase as might be anticipated from a desorption effect of dsDNA due to duplex formation. As previously discussed, this was consistent with criticism of the conventional Langmuir-Hinshelwood hybridized probe and target surface hybridization and detachment model [26]. Instead, a proposed mechanism of nonspecific probe displacement from GO, followed by hybridization in the solution phase, implied that only a small proportion of the added cDNA would undergo surface hybridization. An additional, rarely considered complication was that hybridization may itself quench a conjugated fluorophore via a DNA sequence-specific nucleobase photoinduced electron transfer (PET) reaction. By choosing a DNA probe with three terminal cytosine bases adjacent to the FAM fluorophore, hybridization would bring complementary guanine nucleobases close to the fluorophore, the most oxidizable nucleobase with a relatively strong fluorescence quenching effect [53]. Alternative oligonucleotide sequences may behave differently, but our probe was able to demonstrate the potential significance of a PET effect relative to GO-based FRET quenching. Notably, the extent of quenching from PET seen when FAM-DNA and cDNA were combined alone (about $12 \%$ ), was of the same order of magnitude as the non-significant reduction in fluorescence when GO was added to FAM-DNA and cDNA. Thus, PET may have played a role in our not observing a clear increase in fluorescence when cDNA was added to GO with the FAM-DNA probe. 
The increasing $\mathrm{MgCl}_{2}$ concentration was clearly correlated to the increased FAM-DNA and cDNA target-probe interaction and increased binding of the oligonucleotides to the GO surface. Gel electrophoresis characterization of the oligonucleotides remaining in the solution indicated a preference for ssDNA binding over dsDNA to the $\mathrm{GO}\left(\mathrm{r}^{2}>95 \%\right)$. Ultimately, at $\mathrm{MgCl}_{2}$ concentrations above $1 \mathrm{mM}$, both ssDNA and dsDNA bound strongly to GO and the FAM-DNA was effectively all quenched, even in the presence of cDNA. Thus, increasing the salt concentration could increase dsDNA binding to GO to an excessive extent (Supplementary Figure S1).

Triton X-100 clearly modulated the strong $\mathrm{MgCl}_{2}$ effect on oligonucleotide- $\mathrm{GO}$ binding, extending prior observations that it modulated DNA target-probe interactions [54] to oligonucleotide-nanomaterial interactions as well. In complex solutions, the enhanced variable partitioning of target-probe binding could increase the ssDNA probe selectivity toward hydrophilic steroid analytes. Such a reduction in non-specific interactions could increase the binding affinity between the probe and the target. Among a range of common surfactants spanning cationic, anionic, non-ionic and zwitterionic states, Triton X-100, Tween-20 (both neutral and non-ionic) and SDS (anionic), unlike zwitterionic or positively charged alternatives, maintained a good oligonucleotide biosensor response [54]. Hydrophobic interactions played an important role in the binding of either SDS or Triton $\mathrm{X}-100$ to GO [55]. However, above $1 \mathrm{mM} \mathrm{MgCl}_{2}$, the oligonucleotides were strongly bound to the GO and both Triton X-100 and Tween-20 were only partially effective at relinquishing this strong binding. Thus, this set of conditions was criticized as establishing GO-oligonucelotide binding that may be too strong for establishing effective desorption-based biosensors [55]. An additional concern was that $\mathrm{Mg}^{2+}$ ions may assist DNAse I binding activity [56], destabilizing the DNA sensor performance. Given the possibility of $\mathrm{Mg}^{2+}$-dependent DNAse contaminants being present in physiological samples, the use of $\mathrm{NaCl}$ instead of $\mathrm{Mg}^{2+}$ was preferred. Advantageously, the use of $\mathrm{Na}^{+}$ions allowed for the use of surfactant SDS that would otherwise precipitate in the presence of $\mathrm{Mg}^{2+}$ ions. SDS could markedly reduce non-specific binding in hybridization reactions [57], with the additional benefit of an ability to suppress nuclease activity. This surfactant was preferred to Triton X-100 or Tween-20 for maintaining GO as a stable colloid $[55,58]$ and, above a $40 \mu \mathrm{M}$ concentration, SDS could maintain stable graphenic colloidal suspensions for over a year [21]. The order of the assay buffer preparation steps was important; the initial non-covalent modification of GO with SDS before its exposure to BSA was key to preventing GO aggregation. SDS may have stronger adsorption to GO than other surfactants [55]; however, as a blocking agent, it did not inhibit probe DNA adsorption. Our results were consistent with observations that the use of GO surface-blocking agents could increase DNA biosensor sensitivity [59].

The detection-1 strategy, combining GO together with the probe FAM-DNA and the subsequent measurement of desorbed FAM-DNA hybridized to cDNA targets was complicated by surface target-probe hybridization being more complex than the faster, more straightforward, solution-phase DNA hybridization $[51,60,61]$. Furthermore, it introduced problems in discriminating between the signal contribution of PET and/or FRET quenching towards the final measurement. The detection-2 strategy involved two steps-first, DNA hybridization (detectable by PET), and then the addition of GO to preferentially adsorb the unhybridized FAM-DNA probe (detected by FRET), which allowed PET real-time monitoring of target-probe DNA hybridization, in order to establish its completion before the addition of GO (Supplementary Figure S3). The subsequent GO-specific FRET quenching of the unbound probe provided a more accurate measurement of the target-probe complexes in the solution, an approach similar to that described by Giuliodori et al. [28], who found that GO treatment could drastically sequester ssDNA PCR primers, while marginally affecting dsDNA. Our novel assay preparation method, including the use of SDS, resolved the problems described when BSA was used [28]. 


\section{Conclusions}

We report the sensitive detection of a 30 mer single-stranded DNA target in more pragmatic complex media containing the anionic surfactant SDS, salts and bovine serum albumin, overcoming previously reported problems when using GO biosensors in the context of protein-containing solutions. The FAM-ssDNA probe showed linearity to cDNA hybridization in the range of $1-8 \mathrm{nM} \mathrm{L}^{-1}$ and the limit of quantitation (LOQ) was $1 \mathrm{nM} \mathrm{L}^{-1}$ or 0.1 pmoles $/ 100 \mathrm{uL}$ in the assay mix. The two-step modified "turn off" low-background strategy allowed for the specific monitoring of target-probe hybridization via oligonucleotide PET quenching, followed by the GO adsorption of unbound excess probes detected by GO FRET quenching. The emerging general principles were that one could sensitively measure a low level of target oligonucleotides in complex solutions by the use of PET to monitor specific DNA hybridization, the use of a select surfactant to maintain good GO colloid dispersion in the presence of BSA and the modulation of a compatible monovalent ion concentration for the desired selective GO adsorption of unbound excess ssDNA probes. The non-covalent modification of GO with SDS and BSA was key to preventing GO aggregation, facilitating its use in advanced biological sensors for targeted oligonucleotide detection in protein-containing solutions.

Supplementary Materials: The following are available online at http://www.mdpi.com/2079-6412/10/4/420/s1, Figure S1: FAM-ssDNA and FAM-dsDNA separation by electrophoresis on 5\% agarose gel, Table S1: FAM-ssDNA and FAM-dsDNA relative quantitation by densitometry, Figure S2: FAM-DNA binding to GO in the presence of SDS, BSA and NaCl, Figure S3: FAM-DNA binding to GO in the presence of SDS, BSA and NaCl, FAM-DNA+cDNA hybridization control.

Author Contributions: Conceptualization, F.R.N., J.S.B. and M.I.; methodology, F.R.N.; software, F.R.N.; validation, F.R.N.; formal analysis, F.R.N.; investigation, F.R.N., J.S.B. and M.I.; resources, F.R.N., J.S.B. and M.I.; data curation, F.R.N.; writing-original draft preparation, F.R.N. and M.I.; writing-review and editing, J.S.B., F.R.N. and M.I.; project administration, J.S.B. and M.I.; funding acquisition, J.S.B. and M.I. All authors have read and agreed to the published version of the manuscript.

Funding: This work was supported by a grant from the Ministry of Research and Innovation, Operational Program Competitiveness Axis1 Section E, Program co-financed by the European Regional Development Fund "Investments for your future" under the project number 154/25.11.2016, P_37_221/2015, “A novel graphene biosensor testing osteogenic potency; capturing best stem cell performance for regenerative medicine" (GRABTOP).

Acknowledgments: We thank Diana Becheru, Faculty of Medical Engineering, University Politehnica of Bucharest for helpful discussions during the preparation of this work.

Conflicts of Interest: The authors declare no conflict of interest.

\section{References}

1. Geim, A.K.; Novoselov, K.S. The rise of graphene. Nat. Mater. 2007, 6, 183-191. [CrossRef] [PubMed]

2. Zhang, X.; Wang, H.; Huang, T.; Wen, L.; Zhou, L. Synthesis of graphene oxide through different oxidation degrees for solar cells. Mater. Res. Express 2018, 5, 035515. [CrossRef]

3. Wang, X.; Zhi, L.; Müllen, K. Transparent, Conductive Graphene Electrodes for Dye-Sensitized Solar Cells. Nano Lett. 2008, 8, 323-327. [CrossRef] [PubMed]

4. Li, X.; Zhu, Y.; Cai, W.; Borysiak, M.; Han, B.; Chen, D.; Piner, R.D.; Colombo, L.; Ruoff, R.S. Transfer of Large-Area Graphene Films for High-Performance Transparent Conductive Electrodes. Nano Lett. 2009, 9, 4359-4363. [CrossRef]

5. Yang, Z.; Gao, R.; Hu, N.; Chai, J.; Cheng, Y.; Zhang, L.; Wei, H.; Kong, E.S.-W.; Zhang, Y. The Prospective Two-Dimensional Graphene Nanosheets: Preparation, Functionalization and Applications. Nano-Micro Lett. 2012, 4, 1-9. [CrossRef]

6. Politano, G.G.; Cazzanelli, E.; Versace, C.; Vena, C.; De Santo, M.P.; Castriota, M.; Ciuchi, F.; Bartolino, R. Graphene oxide on magnetron sputtered silver thin films for SERS and metamaterial applications. Appl. Surf. Sci. 2018, 427, 927-933. [CrossRef]

7. Kuila, T.; Bose, S.; Khanra, P.; Mishra, A.K.; Kim, N.H.; Lee, J.H. Recent advances in graphene-based biosensors. Biosens. Bioelectron. 2011, 26, 4637-4648. [CrossRef]

8. Wang, Y.; Li, Z.; Wang, J.; Li, J.; Lin, Y. Graphene and graphene oxide: Biofunctionalization and applications in biotechnology. Trends Biotechnol. 2011, 29, 205-212. [CrossRef] 
9. Morales-Narvaez, E.; Merkoçi, A. Graphene Oxide as an Optical Biosensing Platform: A Progress Report. Adv. Mater. 2019, 31, e1805043. [CrossRef]

10. Zhu, Z. An Overview of Carbon Nanotubes and Graphene for Biosensing Applications. Nano-Micro Lett. 2017, 9, 25. [CrossRef]

11. Yoo, J.M.; Kang, J.H.; Hong, B.H. Graphene-based nanomaterials for versatile imaging studies. Chem. Soc. Rev. 2015, 44, 4835-4852. [CrossRef] [PubMed]

12. Paul, T.; Bera, S.C.; Agnihotri, N.; Mishra, P.P. Single-Molecule FRET Studies of the Hybridization Mechanism during Noncovalent Adsorption and Desorption of DNA on Graphene Oxide. J. Phys. Chem. B 2016, 120, 11628-11636. [CrossRef] [PubMed]

13. Piao, Y.; Liu, F.; Seo, T.S. The photoluminescent graphene oxide serves as an acceptor rather than a donor in the fluorescence resonance energy transfer pair of Cy3.5-graphene oxide. Chem. Commun. 2011, 47, 12149-12151. [CrossRef] [PubMed]

14. He, S.; Song, B.; Li, D.; Zhu, C.; Qi, W.; Wen, Y.; Wang, L.; Song, S.; Fang, H.; Fan, C. A Graphene Nanoprobe for Rapid, Sensitive, and Multicolor Fluorescent DNA Analysis. Adv. Funct. Mater. 2010, 20, 453-459. [CrossRef]

15. Gowtham, S.; Scheicher, R.H.; Ahuja, R.; Pandey, R.; Karna, S.P. Physisorption of nucleobases on graphene: Density-functional calculations. Phys. Rev. B 2007, 76, 033401. [CrossRef]

16. Husale, B.S.; Sahoo, S.; Radenovic, A.; Traversi, F.; Annibale, P.; Kis, A. ssDNA Binding Reveals the Atomic Structure of Graphene. Langmuir 2010, 26, 18078-18082. [CrossRef]

17. Varghese, N.; Mogera, U.; Govindaraj, A.; Das, A.; Maiti, P.K.; Sood, A.K.; Rao, C.N.R. Binding of DNA Nucleobases and Nucleosides with Graphene. ChemPhysChem 2009, 10, 206-210. [CrossRef]

18. Liu, M.; Zhao, H.; Chen, S.; Yu, H.; Quan, X. Capture of double-stranded DNA in stacked-graphene: Giving new insight into the graphene/DNA interaction. Chem. Commun. 2012, 48, 564-566. [CrossRef]

19. Lei, H.; Mi, L.; Zhou, X.; Chen, J.; Hu, J.; Guo, S.; Zhang, Y. Adsorption of double-stranded DNA to graphene oxide preventing enzymatic digestion. Nanoscale 2011, 3, 3888-3892. [CrossRef]

20. Shi, H.; Xiang, W.; Liu, C.; Shi, H.; Zhou, Y.; Gao, L. Highly Sensitive Detection for Cocaine Using Graphene Oxide-Aptamer Based Sensors in Combination with Tween 20. Nanosci. Nanotechnol. Lett. 2018, 10, 1707-1712. [CrossRef]

21. Hsieh, A.G.; Korkut, S.; Punckt, C.; Aksay, I.A. Dispersion Stability of Functionalized Graphene in Aqueous Sodium Dodecyl Sulfate Solutions. Langmuir 2013, 29, 14831-14838. [CrossRef] [PubMed]

22. Ullah, Z.; Witjaksono, G.; Nawi, I.; Tansu, N.; Irfan Khattak, M.; Junaid, M. A Review on the Development of Tunable Graphene Nanoantennas for Terahertz Optoelectronic and Plasmonic Applications. Sensors 2020, 20, 1401. [CrossRef] [PubMed]

23. Soler, M.; Huertas, C.S.; Lechuga, L.M. Label-free plasmonic biosensors for point-of-care diagnostics: A review. Expert Rev. Mol. Diagn. 2019, 19, 71-81. [CrossRef] [PubMed]

24. Liu, R.; Wei, Z.; Hu, Z.; Li, M.; Zhao, Y. Viewing the Interaction Between Double Strand Deoxyribonucleic Acid and Graphene Oxide via Atomic Force Microscopy. J. Nanosci. Nanotechnol. 2016, 16, 4120-4125. [CrossRef] [PubMed]

25. Lu, C.-H.; Yang, H.-H.; Zhu, C.-L.; Chen, X.; Chen, G.-N. A Graphene Platform for Sensing Biomolecules. Angew. Chem. Int. Ed. 2009, 48, 4785-4787. [CrossRef]

26. Liu, B.; Sun, Z.; Zhang, X.; Liu, J. Mechanisms of DNA Sensing on Graphene Oxide. Anal. Chem. 2013, 85, 7987-7993. [CrossRef]

27. Li, F.; Huang, Y.; Yang, Q.; Zhong, Z.; Li, D.; Wang, L.; Song, S.; Fan, C. A graphene-enhanced molecular beacon for homogeneous DNA detection. Nanoscale 2010, 2, 1021-1026. [CrossRef]

28. Giuliodori, A.M.; Brandi, A.; Kotla, S.; Perrozzi, F.; Gunnella, R.; Ottaviano, L.; Spurio, R.; Fabbretti, A. Development of a graphene oxide-based assay for the sequence-specific detection of double-stranded DNA molecules. PLoS ONE 2017, 12, e0183952. [CrossRef]

29. Ding, S.; Cargill, A.A.; Das, S.R.; Medintz, I.L.; Claussen, J.C. Biosensing with Förster Resonance Energy Transfer Coupling between Fluorophores and Nanocarbon Allotropes. Sensors 2015, 15, 14766-14787. [CrossRef]

30. Reina, G.; Chau, N.D.Q.; Nishina, Y.; Bianco, A. Graphene oxide size and oxidation degree govern its supramolecular interactions with siRNA. Nanoscale 2018, 10, 5965-5974. [CrossRef] 
31. Lee, G.M.; Rasch, E.M.; Musich, P.R. Improved in situ hybridization and G-banding by pretreatment with Denhardt's solution and gelatin-chrome alum. Histochem. J. 1985, 17, 1221-1233. [CrossRef] [PubMed]

32. Tan, X.; Feng, L.; Zhang, J.; Yang, K.; Zhang, S.; Liu, Z.; Peng, R. Functionalization of Graphene Oxide Generates a Unique Interface for Selective Serum Protein Interactions. ACS Appl. Mater. Interfaces 2013, 5, 1370-1377. [CrossRef] [PubMed]

33. Lee, J.; Yim, Y.; Kim, S.; Choi, M.-H.; Choi, B.-S.; Lee, Y.; Min, D.-H. In-depth investigation of the interaction between DNA and nano-sized graphene oxide. Carbon 2016, 97, 92-98. [CrossRef]

34. Vlăsceanu, G.M.; Amarandi, R.M.; Ionita, M.; Tite, T.; Iovu, H.; Pilan, L.; Burns, J.S. Versatile graphene biosensors for enhancing human cell therapy. Biosens. Bioelectron. 2018, 117, 283-302. [CrossRef]

35. Becheru, D.F.; Vlăsceanu, G.M.; Banciu, A.; Vasile, E.; Ionita, M.; Burns, J.S. Optical Graphene-Based Biosensor for Nucleic Acid Detection; Influence of Graphene Functionalization and Ionic Strength. Int. J. Mol. Sci. 2018, 19, 3230. [CrossRef]

36. Bao, H.; Pan, Y.; Ping, Y.; Sahoo, N.G.; Wu, T.; Li, L.; Li, J.; Gan, L.H. Chitosan-Functionalized Graphene Oxide as a Nanocarrier for Drug and Gene Delivery. Small 2011, 7, 1569-1578. [CrossRef]

37. Ren, T.; Li, L.; Cai, X.; Dong, H.; Liu, S.; Li, Y. Engineered polyethylenimine/graphene oxide nanocomposite for nuclear localized gene delivery. Polym. Chem. 2012, 3, 2561-2569. [CrossRef]

38. Feng, L.; Zhang, S.; Liu, Z. Graphene based gene transfection. Nanoscale 2011, 3, 1252-1257. [CrossRef]

39. Liu, Z.; Robinson, J.T.; Sun, X.; Dai, H. PEGylated Nanographene Oxide for Delivery of Water-Insoluble Cancer Drugs. J. Am. Chem. Soc. 2008, 130, 10876-10877. [CrossRef]

40. Yang, K.; Feng, L.; Hong, H.; Cai, W.; Liu, Z. Preparation and functionalization of graphene nanocomposites for biomedical applications. Nat. Protoc. 2013, 8, 2392-2403. [CrossRef]

41. Ding, Z.; Zhang, Z.; Ma, H.; Chen, Y. In Vitro Hemocompatibility and Toxic Mechanism of Graphene Oxide on Human Peripheral Blood T Lymphocytes and Serum Albumin. ACS Appl. Mater. Interfaces 2014, 6, 19797-19807. [CrossRef] [PubMed]

42. Min, B.J.; Tran, L.-H.; Jang, S.-H.; Lee, C.W. Tyrosine and Tryptophan Have Different Binding Sites on Graphene Oxide. New Phys. Sae Mulli 2016, 66, 103-107. [CrossRef]

43. McCallion, C.; Burthem, J.; Rees-Unwin, K.; Golovanov, A.; Pluen, A. Graphene in therapeutics delivery: Problems, solutions and future opportunities. Eur. J. Pharm. Biopharm. 2016, 104, 235-250. [CrossRef]

44. Kurata, S.; Kanagawa, T.; Yamada, K.; Torimura, M.; Yokomaku, T.; Kamagata, Y.; Kurane, R. Fluorescent quenching-based quantitative detection of specific DNA/RNA using a BODIPY((R)) FL-labeled probe or primer. Nucleic Acids Res. 2001, 29, e34. [CrossRef] [PubMed]

45. Marras, S.A.E.; Kramer, F.R.; Tyagi, S. Efficiencies of fluorescence resonance energy transfer and contact-mediated quenching in oligonucleotide probes. Nucleic Acids Res. 2002, 30, e122. [CrossRef]

46. Torimura, M.; Kurata, S.; Yamada, K.; Yokomaku, T.; Kamagata, Y.; Kanagawa, T.; Kurane, R. Fluorescence-Quenching Phenomenon by Photoinduced Electron Transfer between a Fluorescent Dye and a Nucleotide Base. Anal. Sci. 2001, 17, 155-160. [CrossRef]

47. Zhou, X.; Liao, Y.; Xing, D. Sensitive monitoring of RNA transcription levels using a graphene oxide fluorescence switch. Chin. Sci. Bull. 2013, 58, 2634-2639. [CrossRef]

48. Chiticaru, E.A.; Pilan, L.; Damian, C.-M.; Vasile, E.; Burns, J.S.; Ioniţă, M. Influence of Graphene Oxide Concentration when Fabricating an Electrochemical Biosensor for DNA Detection. Biosensors 2019, 9, 113. [CrossRef]

49. Wu, M.; Kempaiah, R.; Huang, P.J.; Maheshwari, V.; Liu, J. Adsorption and Desorption of DNA on Graphene Oxide Studied by Fluorescently Labeled Oligonucleotides. Langmuir 2011, 27, 2731-2738. [CrossRef] [PubMed]

50. Ding, Y.; Shu, Y.; Ge, L.; Guo, R. The effect of sodium dodecyl sulfate on the conformation of bovine serum albumin. Colloids Surf. A: Physicochem. Eng. Asp. 2007, 298, 163-169. [CrossRef]

51. Gong, P.; Levicky, R. DNA surface hybridization regimes. Proc. Natl. Acad. Sci. USA 2008, 105, 5301-5306. [CrossRef] [PubMed]

52. Liu, B.; Salgado, S.; Maheshwari, V.; Liu, J. DNA adsorbed on graphene and graphene oxide: Fundamental interactions, desorption and applications. Curr. Opin. Colloid Interface Sci. 2016, 26, 41-49. [CrossRef]

53. Seidel, C.A.M.; Schulz, A.; Sauer, M.H.M. Nucleobase-Specific Quenching of Fluorescent Dyes. 1. Nucleobase One-Electron Redox Potentials and Their Correlation with Static and Dynamic Quenching Efficiencies. J. Phys. Chem. 1996, 100, 5541-5553. [CrossRef] 
54. Peterson, A.M.; Jahnke, F.M.; Heemstra, J.M. Modulating the Substrate Selectivity of DNA Aptamers Using Surfactants. Langmuir 2015, 31, 11769-11773. [CrossRef]

55. Zhang, F.; Li, S.; Zhang, Q.; Liu, J.; Zeng, S.; Liu, M.; Sun, D. Adsorption of different types of surfactants on graphene oxide. J. Mol. Liq. 2019, 276, 338-346. [CrossRef]

56. Guéroult, M.; Picot, D.; Abi-Ghanem, J.; Hartmann, B.; Baaden, M. How Cations Can Assist DNase I in DNA Binding and Hydrolysis. PLoS Comput. Biol. 2010, 6, e1001000. [CrossRef]

57. Rose, K.; Mason, J.O.; Lathe, R. Hybridization Parameters Revisited: Solutions Containing SDS. Biotechniques 2002, 33, 54-58. [CrossRef]

58. Amoli, B.M.; Trinidad, J.; Rivers, G.; Sy, S.; Russo, P.; Yu, A.; Zhou, N.Y.; Zhao, B. SDS-stabilized graphene nanosheets for highly electrically conductive adhesives. Carbon 2015, 91, 188-199. [CrossRef]

59. Liu, B.; Huang, P.J.; Kelly, E.Y. Graphene oxide surface blocking agents can increase the DNA biosensor sensitivity. Biotechnol. J. 2016, 11, 780-787. [CrossRef]

60. Wilkins Stevens, P.; Henry, M.R.; Kelso, D.M. DNA hybridization on microparticles: Determining capture-probe density and equilibrium dissociation constants. Nucleic Acids Res. 1999, 27, 1719-1727. [CrossRef]

61. Sekar, M.M.A.; Bloch, W.; St John, P.M. Comparative study of sequence-dependent hybridization kinetics in solution and on microspheres. Nucleic Acids Res. 2005, 33, 366-375. [CrossRef] [PubMed]

(C) 2020 by the authors. Licensee MDPI, Basel, Switzerland. This article is an open access article distributed under the terms and conditions of the Creative Commons Attribution (CC BY) license (http://creativecommons.org/licenses/by/4.0/). 